\title{
Experimental Investigation of the Binary Mn-Sb Phase Diagram
}

\author{
Peter Kainzbauer, Klaus W. Richter, and Herbert Ipser
}

(Submitted March 8, 2016; in revised form April 15, 2016; published online May 25, 2016)

\begin{abstract}
The binary manganese-antimony (Mn-Sb) phase diagram was reinvestigated in the whole composition range using powder-XRD, DTA and SEM-EDX. The phase boundaries and melting temperatures of the ferromagnetic phases $\mathrm{MnSb}$ and $\mathrm{Mn}_{2} \mathrm{Sb}$ were modified by taking into account the new experimental data. Most of the reaction temperatures could be verified within a range of $\pm 10^{\circ} \mathrm{C}$. Nevertheless, a few temperatures had to be revised, such as the eutectic reaction $L \rightarrow \beta-M n+M n_{2} S b$ at $893{ }^{\circ} \mathrm{C}$ and the eutectoid reaction $\beta-M n \rightarrow \alpha-M n+M n_{2} S b$ at $718^{\circ} \mathrm{C}$. The previously reported peritectic melting behavior of MnSb could be confirmed. The variation of the lattice parameters of the $\mathrm{NiAs}-\left(B 8_{1}\right)$ type $\mathrm{MnSb}$ phase with composition was determined. A revised version of the of the Mn-Sb phase diagram is presented.
\end{abstract}

Keywords melting temperatures, Mn-Sb system, phase boundaries, phase diagram

\section{Introduction}

Binary intermetallic phases based on $3 d$ metals and group 15 elements like $\mathrm{MnSb}, \mathrm{MnBi}, \mathrm{Mn}_{2} \mathrm{Sb}$ are interesting technical materials. Since the discovery of ferromagnetic iron-free manganese alloys by Heusler ${ }^{[1]}$ these phases were frequently investigated by various authors, ${ }^{[1-8]}$ especially for their superior ferromagnetic and magneto-optical properties. Although several studies on phase composition, crystal structure, and magnetic properties of $\mathrm{MnSb}$ and $\mathrm{Mn}_{2} \mathrm{Sb}$ can be found in the literature, both at normal ${ }^{[9-13]}$ as well as at high pressures, ${ }^{[14-17]}$ only a few experimental studies were published on the whole binary Mn-Sb system since the first investigation by Williams. ${ }^{[10]}$ An assessment of the Mn-Sb system was given by Massalski ${ }^{[18]}$ and Predel, ${ }^{[19]}$ it is presented in Fig. 1. Even though the published phase diagram was based on experimental data from several authors ${ }^{[9-12,20,21]}$ there were many uncertainties remaining, in particular with respect to the phase boundaries of solid phases: thus, the exact stability range of $\mathrm{Mn}_{2} \mathrm{Sb}$ and $\mathrm{MnSb}$ was not known.

Phases with the NiAs structure, such as MnSb, crystallize in the hexagonal space group $P 6_{3} / m m c$. This structure type is characterized by atoms of a main group element $B(\mathrm{Sb})$, forming a hexagonal closed packed lattice on Wyckoff position $2 c(1 / 3,2 / 3,1 / 4)$ with the octahedral sites being occupied by transition metal atoms $T(\mathrm{Mn})$, on Wyckoff position $2 a(0,0,0)$. In general, the stoichiometry of the

Peter Kainzbauer, Klaus W. Richter, and Herbert Ipser, Department of Inorganic Chemistry - Functional Materials, University of Vienna, Währingerstraße 42, 1090 Vienna, Austria. Contact e-mail: peter.kainzbauer@univie.ac.at.
NiAs-type phases may vary from $T B_{2}$ all the way to to $T_{2} B$, including the ideal composition of $T B$. An overview about the properties of phases with the NiAs structure was given by Kjekshus and Pearson. ${ }^{[22]}$

The aim of the present study is to resolve the uncertainties regarding the $\mathrm{Mn}-\mathrm{Sb}$ phase equilibria and to provide an experimental investigation of the entire $\mathrm{Mn}-\mathrm{Sb}$ phase diagram at temperatures above $500{ }^{\circ} \mathrm{C}$. Particular emphasis was placed on the melting behavior of the phase $\mathrm{MnSb}$ : although it had been shown to decompose in a peritectic reaction in the earlier literature, a congruent melting point could not be entirely excluded based on the experimental liquidus data as well as on the microstructure of samples in the composition range between $\mathrm{MnSb}$ and $\mathrm{Mn}_{2} \mathrm{Sb}^{[23]}$ In addition, the dependence of the lattice parameters of $\mathrm{MnSb}$ on the $\mathrm{Sb}$ content is reported.

\section{Literature Review}

The existing literature ${ }^{[9-12,18,19,21,24-26]}$ on the $\mathrm{Mn}-\mathrm{Sb}$ system still manifests some discrepancies with respect to phase boundaries and reaction temperatures. Chen et al. ${ }^{[26]}$ showed a homogeneity range of the MnSb phase at $700{ }^{\circ} \mathrm{C}$ about 44 and 50 at.\% $\mathrm{Sb}$ and a peritectic decomposition temperature of $843{ }^{\circ} \mathrm{C}$. Teramoto and van Run ${ }^{[24]}$ reported its homogeneity range between about 44 and 49 at.\% $\mathrm{Sb}$ at $700{ }^{\circ} \mathrm{C}$ and showed a peritectic temperature of about $840{ }^{\circ} \mathrm{C}$. Vanyarkho et al. ${ }^{[12]}$ also reported a peritectic temperature of $840{ }^{\circ} \mathrm{C}$ with the peritectic composition extrapolated at 41 at. $\% \mathrm{Sb}$; they show a homogeneity range at $700{ }^{\circ} \mathrm{C}$ between 42.5 and 48 at. $\% \mathrm{Sb}$. All of these authors agree that $\mathrm{MnSb}$ shows a more or less strong retrograde solubility on the Mn-rich side with the phase boundary shifting to higher Sb contents at lower temperatures. This is in line with the shift of the Mn-rich boundary reported by Askheim and Grønvold, ${ }^{[9]}$ i.e. from about 43.8 at.\% $\mathrm{Sb}$ at $700{ }^{\circ} \mathrm{C}$ to about 46.2 at. $\% \mathrm{Sb}$ at $200{ }^{\circ} \mathrm{C}$. Recent work by 


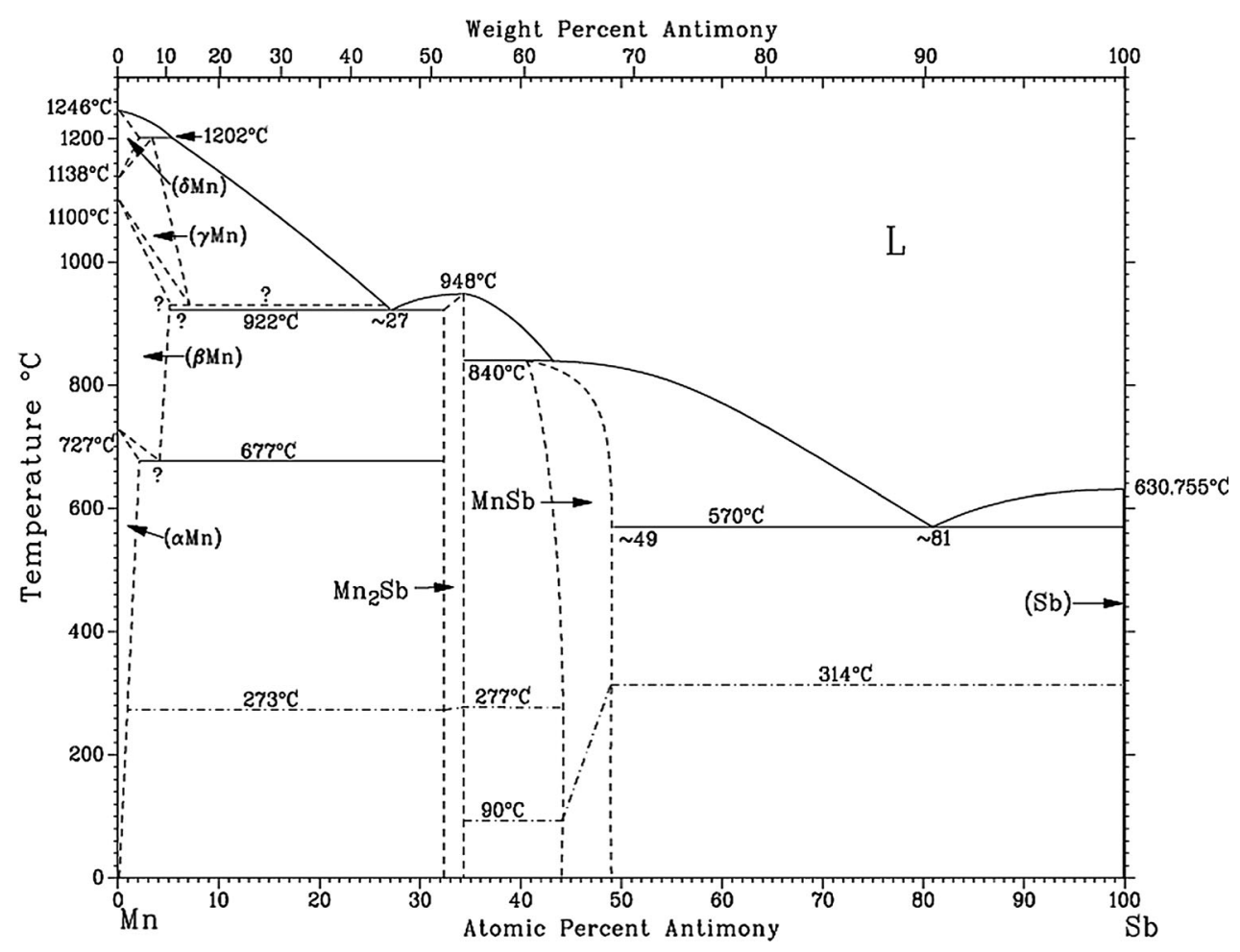

Fig. 1 Mn-Sb phase diagram according to Massalski et al. ${ }^{[16]}$

Romaka et al. ${ }^{[25]}$ reported the solubility limits of $\mathrm{MnSb}$ between 47.19 and 53.45 at. $\% \mathrm{Sb}$ at $600{ }^{\circ} \mathrm{C}$ from a study of the ternary $\mathrm{Mn}-\mathrm{Sb}-\mathrm{Zr}$ system.

Williams ${ }^{[10]}$ mentioned the congruent melting temperature of $\mathrm{Mn}_{2} \mathrm{Sb}\left(33.1 \pm 0.3\right.$ at.\% Sb) at $919{ }^{\circ} \mathrm{C}$ and a homogeneity range of 31 to 35 at.\% Sb which is in a good agreement with the high-temperature homogeneity range between 31 and 36 at.\% Sb reported by Murakami and Hatta. ${ }^{[21]}$ Later on, Askheim and Grønvold ${ }^{[9]}$ described a "shift of the composition of the $\mathrm{Mn}_{2} \mathrm{Sb}$ phase" from 33.3 at. $\% \mathrm{Sb}$ at $600-700{ }^{\circ} \mathrm{C}$ to 32.4 at. $\% \mathrm{Sb}$ at $250{ }^{\circ} \mathrm{C}$ and mentioned a congruent melting temperature of $948{ }^{\circ} \mathrm{C}$. In their assessment, Massalski et al. ${ }^{[18]}$ show a temperature independent homogeneity range between about 32.3 and 34.5 at. $\% \mathrm{Sb}$ for $\mathrm{Mn}_{2} \mathrm{Sb}$ and a congruent melting temperature of $948{ }^{\circ} \mathrm{C}$ at about 34.3 at.\% Sb. The eutectic $L \rightarrow M n S b+S b$ is reported by Massalski et al. ${ }^{[18]}$ at approximately 81 at. $\% \mathrm{Sb}$ and $570{ }^{\circ} \mathrm{C}$ which was confirmed by more recent work by Liu et al. ${ }^{[27]}$. The eutectic $L \rightarrow \beta-M n+\mathrm{Mn}_{2} \mathrm{Sb}$ was reported at approximately 27 at. $\% \mathrm{Sb}$ and $922{ }^{\circ} \mathrm{C}$ by Massalski et al. ${ }^{[18]}$ The Mn$\mathrm{Sb}$ phase diagram, as shown in the literature[18], is presented in Fig. 1.

Several reports can be found in the literature on the behavior of $\mathrm{Mn}-\mathrm{Sb}$ alloys at high pressures (see, for example, Ryzhkovskii et al., Goncharov and Ryzhkovskii, Yamashita et al., Ryzhkovskii and Goncharov ${ }^{[14-17]}$ as well as references therein). This includes an $\mathrm{L1}_{2}$-type phase $\mathrm{Mn}_{3} \mathrm{Sb}$ which, however, is not stable at ambient pressure.

Besides the heat capacity data for $\mathrm{Mn}_{2} \mathrm{Sb}$ by Askheim and Grønvold ${ }^{[9]}$ no other thermodynamic information on
$\mathrm{Mn}-\mathrm{Sb}$ alloys could be found in the literature. In their CALPHAD-type assessment of the ternary Bi-Mn-Sb system, Uemitsu et al. ${ }^{[30]}$ optimized also the binary Mn$\mathrm{Sb}$ system. However, this was solely based on phase diagram information except for the heat capacity of $\mathrm{Mn}_{2} \mathrm{Sb}$ from Askheim and Grønvold. ${ }^{[9]}$

\section{Experimental}

\subsection{Sample Preparation}

Most of the samples containing more than 33 at.\% Sb were prepared from pure element pieces (Mn, 99.95\%, and Sb, 99.999\%; both Alfa Aesar, Johnson Matthey Chemicals, Karlsruhe, Germany) which were weighed under Ar atmosphere in a glove box (Labmaster SP MBraun, $\mathrm{O}_{2}$ and $\mathrm{H}_{2} \mathrm{O}$ level: $<1 \mathrm{ppm}$ each). They were sealed into evacuated silica glass tubes $\left(\sim 10^{-3}\right.$ bar $)$ and melted over an oxyhydrogen flame under shaking and with optical control of the melting process. The total amount of each sample was about $1000 \mathrm{mg}$. All samples except one were annealed at different temperatures for at least two weeks. The sample $\mathrm{Mn}_{59.8} \mathrm{Sb}_{40.2}$ was quenched in cold water immediately after melting instead of annealing.

All other samples were produced from the same materials, but the $\mathrm{Mn}$ and $\mathrm{Sb}$ pieces were manually powdered under Ar atmosphere in the glove box, and the powder mixtures were filled into a $5 \mathrm{~mm}$ pressing cylinder, sealed tightly with Parafilm ${ }^{\circledR}$, and pressed into pellets under a load of $20-25 \mathrm{kN}$. The pellets were placed into alumina (Alox) 
Table 1 Experimental phase compositions and cell parameters of selected samples

\begin{tabular}{|c|c|c|c|c|c|c|}
\hline \multirow[b]{2}{*}{ Sample comp./at\% } & \multirow[b]{2}{*}{ Annealing duration/temperature $\mathbf{h} /{ }^{\circ} \mathrm{C}$} & \multicolumn{2}{|r|}{ XRD } & \multicolumn{2}{|c|}{ EDX } & \multirow[b]{2}{*}{ Prep. method } \\
\hline & & Phase & Lattice parameters/Å & Mn/at\% & $\mathrm{Sb} / \mathbf{a t} \%$ & \\
\hline \multirow[t]{2}{*}{$\mathrm{Mn}_{15} \mathrm{Sb}_{85}$} & $340 / 600$ & $\mathrm{MnSb}$ & $a=4.130(9) c=5.800(7)$ & $\ldots$ & $\ldots$ & 1 \\
\hline & & $\mathrm{Sb}$ & $a=4.310(1) c=11.273(8)$ & 0.2 & 99.8 & \\
\hline \multirow[t]{2}{*}{$\mathrm{Mn}_{18.4} \mathrm{Sb}_{81.6}$} & $384 / 725$ & $\mathrm{MnSb}$ & $a=4.129(5) c=5.800(9)$ & $\ldots$ & $\ldots$ & 1 \\
\hline & & $\mathrm{Sb}$ & $a=4.308(9) c=11.267(3)$ & $\ldots$ & $\ldots$ & \\
\hline \multirow[t]{2}{*}{$\mathrm{Mn}_{21} \mathrm{Sb}_{79}$} & $340 / 600$ & $\mathrm{MnSb}$ & $a=4.131(1) c=5.794(1)$ & 49.5 & 50.6 & 1 \\
\hline & & $\mathrm{Sb}$ & $a=4.309(7) c=11.274(6)$ & $\ldots$ & $\ldots$ & \\
\hline \multirow[t]{2}{*}{$\mathrm{Mn}_{25.6} \mathrm{Sb}_{74.4}$} & $340 / 600$ & $\mathrm{MnSb}$ & $a=4.134(3) c=5.790(6)$ & 49.8 & 50.2 & 1 \\
\hline & & $\mathrm{Sb}$ & $a=4.309(6) c=11.276(9)$ & $\ldots$ & $\ldots$ & \\
\hline \multirow[t]{2}{*}{$\mathrm{Mn}_{31.8} \mathrm{Sb}_{68.2}$} & $384 / 725$ & $\mathrm{MnSb}$ & $a=4.309(6) c=5.790(3)$ & 49.8 & 50.2 & 1 \\
\hline & & $\mathrm{Sb}$ & $a=4.309(3) c=11.274(6)$ & & & \\
\hline \multirow[t]{2}{*}{$\mathrm{Mn}_{34.4} \mathrm{Sb}_{65.6}$} & $384 / 725$ & $\mathrm{MnSb}$ & $a=4.132(7) c=5.790(6)$ & 49.9 & 50.1 & 1 \\
\hline & & $\mathrm{Sb}$ & $a=4.308(6) c=11.274(4)$ & $\ldots$ & $\ldots$ & \\
\hline \multirow[t]{2}{*}{$\mathrm{Mn}_{39.3} \mathrm{Sb}_{60.7}$} & $340 / 750$ & $\mathrm{MnSb}$ & $a=4.133(4) c=5.791(3)$ & 49.7 & 50.3 & 1 \\
\hline & & $\mathrm{Sb}$ & $a=4.309(5) c=11.276(3)$ & $\ldots$ & $\ldots$ & \\
\hline \multirow[t]{2}{*}{$\mathrm{Mn}_{49.4} \mathrm{Sb}_{50.6}$} & $384 / 725$ & $\mathrm{MnSb}$ & $a=4.141(2) c=5.782(6)$ & 50.2 & 49.9 & 1 \\
\hline & & $\mathrm{Sb}$ & $a=4.310(5) c=11.291(8)$ & $\ldots$ & $\ldots$ & \\
\hline $\mathrm{Mn}_{50.7} \mathrm{Sb}_{49.3}$ & $384 / 725$ & $\mathrm{MnSb}$ & $a=4.148(3) c=5.774(1)$ & 50.1 & 49.7 & 1 \\
\hline $\mathrm{Mn}_{51.5} \mathrm{Sb}_{48.5}$ & $340 / 725$ & $\mathrm{MnSb}$ & $a=4.168(2) c=5.756(5)$ & $\ldots$ & $\ldots$ & 1 \\
\hline $\mathrm{Mn}_{52.3} \mathrm{Sb}_{47.7}$ & $384 / 725$ & $\mathrm{MnSb}$ & $a=4.167(1) c=5.756(3)$ & $\ldots$ & $\ldots$ & 1 \\
\hline $\mathrm{Mn}_{52.7} \mathrm{Sb}_{47.3}$ & $340 / 725$ & $\mathrm{MnSb}$ & $a=4.189(4) c=5.737(4)$ & $\ldots$ & $\ldots$ & 1 \\
\hline $\mathrm{Mn}_{54.5} \mathrm{Sb}_{45.5}$ & $384 / 725$ & $\mathrm{MnSb}$ & $a=4.231(3) c=5.709(3)$ & $\ldots$ & $\ldots$ & 1 \\
\hline \multirow{2}{*}{$\mathrm{Mn}_{55} \mathrm{Sb}_{45}$} & $480 / 800$ & $\mathrm{MnSb}$ & $a=4.228(2) c=5.711(4)$ & 55.0 & 45.0 & 2 \\
\hline & & $\mathrm{Mn}_{2} \mathrm{Sb}$ & $a=4.075(4) c=6.532(2)$ & $\ldots$ & $\ldots$ & \\
\hline \multirow{2}{*}{$\mathrm{Mn}_{56} \mathrm{Sb}_{44}$} & $480 / 800$ & $\mathrm{MnSb}$ & $a=4.225(6) c=5.712(9)$ & 54.2 & 45.8 & 2 \\
\hline & & $\mathrm{Mn}_{2} \mathrm{Sb}$ & $a=4.075(1) c=6.544(6)$ & 63.3 & 36.7 & \\
\hline \multirow[t]{2}{*}{$\mathrm{Mn}_{57.1} \mathrm{Sb}_{42.9}$} & $480 / 800$ & $\mathrm{MnSb}$ & $a=4.224(2) c=5.709(9)$ & 54.8 & 45.2 & 2 \\
\hline & & $\mathrm{Mn}_{2} \mathrm{Sb}$ & $a=4.076(2) c=6.545(2)$ & 65.6 & 34.4 & \\
\hline \multirow[t]{2}{*}{$\mathrm{Mn}_{57.8} \mathrm{Sb}_{42.2}$} & $480 / 800$ & $\mathrm{MnSb}$ & $a=4.231(7) c=5.712(4)$ & 54.5 & 45.5 & 2 \\
\hline & & $\mathrm{Mn}_{2} \mathrm{Sb}$ & $a=4.076(3) c=6.546(5)$ & 65.8 & 34.2 & \\
\hline \multirow[t]{2}{*}{$\mathrm{Mn}_{58.1} \mathrm{Sb}_{41.9}$} & $480 / 725$ & $\mathrm{MnSb}$ & $a=4.238(9) c=5.712(3)$ & 55.4 & 44.6 & 1 \\
\hline & & $\mathrm{Mn}_{2} \mathrm{Sb}$ & $a=4.078(4) c=6.541(7)$ & 65.2 & 34.8 & \\
\hline $\mathrm{Mn}_{59.8} \mathrm{Sb}_{40.2}$ & $\ldots$ & $\mathrm{MnSb}$ & $a=4.238(5) c=5.712(7)$ & 55.7 & 44.3 & 1 \\
\hline & & $\mathrm{Mn}_{2} \mathrm{Sb}$ & $a=4.077(8) c=6.542(3)$ & 65.0 & 35.0 & \\
\hline $\mathrm{Mn}_{59.7} \mathrm{Sb}_{40.3}$ & $480 / 725$ & $\mathrm{MnSb}$ & $a=4.235(9) c=5.707(9)$ & 55.3 & 44.7 & 1 \\
\hline & & $\mathrm{Mn}_{2} \mathrm{Sb}$ & $a=4.077(7) c=6.544(4)$ & 65.3 & 34.7 & \\
\hline $\mathrm{Mn}_{62} \mathrm{Sb}_{38}$ & $480 / 600$ & $\mathrm{MnSb}$ & $a=4.236(8) c=5.711(2)$ & 55.1 & 44.9 & 2 \\
\hline & & $\mathrm{Mn}_{2} \mathrm{Sb}$ & $a=4.077(7) c=6.546(7)$ & 65.5 & 34.5 & \\
\hline $\mathrm{Mn}_{62.3} \mathrm{Sb}_{37.7}$ & $480 / 725$ & $\mathrm{MnSb}$ & $a=4.225(8) c=5.713(5)$ & 54.4 & 45.6 & 1 \\
\hline & & $\mathrm{Mn}_{2} \mathrm{Sb}$ & $a=4.077(3) c=6.546(2)$ & 65.6 & 34.4 & \\
\hline $\mathrm{Mn}_{66} \mathrm{Sb}_{34}$ & $480 / 725$ & $\mathrm{Mn}_{2} \mathrm{Sb}$ & $a=4.077(1) c=6.545(6)$ & 65.9 & 34.1 & 1 \\
\hline $\mathrm{Mn}_{66.1} \mathrm{Sb}_{33.9}$ & $480 / 725$ & $\mathrm{Mn}_{2} \mathrm{Sb}$ & $a=4.076(9) c=6.545(7)$ & 65.6 & 34.4 & 1 \\
\hline $\mathrm{Mn}_{67.5} \mathrm{Sb}_{32.5}$ & $480 / 600$ & $\mathrm{Mn}_{2} \mathrm{Sb}$ & $a=4.076(2) c=6.544(3)$ & 65.9 & 34.1 & 2 \\
\hline & & $\alpha-M n$ & $a=8.892(1)$ & 97.4 & 2.6 & \\
\hline $\mathrm{Mn}_{72.9} \mathrm{Sb}_{27.1}$ & $480 / 725$ & $\mathrm{Mn}_{2} \mathrm{Sb}$ & $a=4.076(7) c=6.547(5)$ & 66.2 & 33.8 & 2 \\
\hline & & $\beta-M n$ & $a=6.362(8)$ & 96.8 & 3.3 & \\
\hline $\mathrm{Mn}_{76.7} \mathrm{Sb}_{23.3}$ & $480 / 600$ & $\mathrm{Mn}_{2} \mathrm{Sb}$ & $a=4.076(4) c=6.547(5)$ & 66.0 & 34.0 & 2 \\
\hline & & $\alpha-\mathrm{Mn}$ & $a=8.935(6)$ & 96.7 & 3.3 & \\
\hline $\mathrm{Mn}_{80} \mathrm{Sb}_{20}$ & $480 / 725$ & $\mathrm{Mn}_{2} \mathrm{Sb}$ & $a=4.076(7) c=6.548(5)$ & 66.4 & 3.6 & 2 \\
\hline & & $\beta-\mathrm{Mn}$ & $a=6.375(1)$ & 96.9 & 3.1 & \\
\hline $\mathrm{Mn}_{83.7} \mathrm{Sb}_{16.3}$ & $480 / 725$ & $\mathrm{Mn}_{2} \mathrm{Sb}$ & $a=4.076(1) c=6.548(4)$ & 66.4 & 33.6 & 2 \\
\hline & & $\beta-M n$ & $a=6.373(9)$ & 96.7 & 3.3 & \\
\hline $\mathrm{Mn}_{92.7} \mathrm{Sb}_{7.3}$ & $480 / 600$ & $\mathrm{Mn}_{2} \mathrm{Sb}$ & $a=4.077(4) c=6.548(2)$ & 66.5 & 33.5 & 2 \\
\hline & & $\alpha-\mathrm{Mn}$ & $a=8.916(2)$ & 97.5 & 2.5 & \\
\hline
\end{tabular}


Table 1 continued

\begin{tabular}{|c|c|c|c|c|c|c|}
\hline \multirow[b]{2}{*}{ Sample comp./at $\%$} & \multirow[b]{2}{*}{ Annealing duration/temperature $\mathbf{h} /{ }^{\circ} \mathrm{C}$} & \multicolumn{2}{|r|}{ XRD } & \multicolumn{2}{|c|}{ EDX } & \multirow[b]{2}{*}{ Prep. method } \\
\hline & & Phase & Lattice parameters $/ \AA ̊ \AA$ & Mn/at\% & $\mathrm{Sb} / \mathrm{at} \%$ & \\
\hline \multirow[t]{2}{*}{$\mathrm{Mn}_{94.1} \mathrm{Sb}_{5.9}$} & $480 / 600$ & $\mathrm{Mn}_{2} \mathrm{Sb}$ & $a=4.076(4) c=6.548(5)$ & 66.4 & 33.6 & 2 \\
\hline & & $\alpha-\mathrm{Mn}$ & $a=8.917(1)$ & 97.5 & 2.4 & \\
\hline \multirow[t]{2}{*}{$\mathrm{Mn}_{94.6} \mathrm{Sb}_{5.4}$} & $480 / 725$ & $\mathrm{Mn}_{2} \mathrm{Sb}$ & $a=4.076(9) c=6.548(1)$ & 66.9 & 33.1 & 2 \\
\hline & & $\beta-\mathrm{Mn}$ & $a=6.379(1)$ & 97.0 & 3.0 & \\
\hline \multirow[t]{2}{*}{$\mathrm{Mn}_{96} \mathrm{Sb}_{4}$} & $480 / 725$ & $\mathrm{Mn}_{2} \mathrm{Sb}$ & $\ldots$ & 68.8 & 31.2 & 2 \\
\hline & & $\beta-\mathrm{Mn}$ & $a=6.374(6)$ & 97.0 & 3.0 & \\
\hline
\end{tabular}

Preparation method (see text): $1=$ melting by flame; 2 = powder pellet

crucibles, sealed into evacuated silica glass tubes $\left(\sim 10^{-3}\right.$ bar), and heated in a furnace to $1100{ }^{\circ} \mathrm{C}$ for 5 min, cooled down within $30 \mathrm{~min}$ to the corresponding annealing temperature and annealed for at least two weeks. Finally, the alloys were quenched in cold water and investigated by standard analytical methods.

All details of sample preparation and annealing are summarized in Table 1 . Due to the reactivity and volatility of $\mathrm{Mn}$, the nominal sample compositions are considered to be less accurate than usual. Therefore, the gross compositions of the samples listed in the Tables 1 and 2 were all derived from scanning electron microscope (SEM) area scans. Depending where the samples are located in the muffle furnace (Nabertherm, Germany) the annealing temperature should be accurate within approximately $\pm 10{ }^{\circ} \mathrm{C}$.

Phase identification was done by powder-x-ray diffraction (XRD) on a Bruker D8 Advance Diffractometer in Bragg-Brentano pseudo-focusing geometry (reflection setting) at ambient conditions, using $\mathrm{Cu}-\mathrm{K}_{\alpha}$ radiation. Data were collected by a LynxEye ${ }^{\circledR}$ one-dimensional silicon strip detector (exposure time $2 \mathrm{~h}$ ). Analysis and refinement of the powder patterns were done with the TOPAS ${ }^{\circledR}$ 4-2 software $^{[28]}$ applying the Rietveld method.

Metallographic investigations were performed on polished samples by utilizing a scanning electron microscope (SEM) (Zeiss Supra $55 \mathrm{VP}$ ) with energy-dispersive x-ray spectroscopy (EDX). Backscattered electrons were used for visualizing the surface at $20 \mathrm{kV}$ acceleration voltage. For the calibration of the EDX detector, the pure elements $\mathrm{Mn}$ and $\mathrm{Sb}$ were used as standard materials and pure Co was employed for the energy calibration. The average phase composition was obtained from at least eight spot/area scans in order to minimize statistical errors.

Differential thermal analyses (DTA) were performed on a DSC 404F1 Pegasus (Netzsch, Selb, Germany) applying evacuated silica glass crucibles $\left(\sim 10^{-3}\right.$ bar $)$ for temperatures below $1100{ }^{\circ} \mathrm{C}$, and closed Ta crucibles for temperatures above $1100{ }^{\circ} \mathrm{C}$. Zirconium was used as reference material. The temperature program included two heating and cooling cycles with a heating/cooling rate of 5 or $0.5 \mathrm{~K} /$ min in some special cases, (see Table 2), starting from the annealing temperature up to about $50{ }^{\circ} \mathrm{C}$ above the estimated liquidus temperature. Temperature measurements were performed with type $\mathrm{S}(\mathrm{Pt} / \mathrm{PtRh})$ thermocouples which had been calibrated at the melting points of $\mathrm{Ag}, \mathrm{Au}, \mathrm{Sb}, \mathrm{Sn}$. In order to prevent a reaction between the samples and the crucible material, the silica glass crucibles were protected by a carbon layer and the Ta crucibles by using a hexagonal boron nitride $(\mathrm{BN})$ inlay.

\section{Results and Discussion}

Sample compositions, heat treatments, and the results of powder-XRD and EDX are summarized in Table 1. The results of the DTA measurements are shown in Table 2; for the cases where Mn has reacted with the carbonized silica glass tubes during the DTA measurements, only the results of the first heating and cooling cycle were used and listed in the table.

The complete $\mathrm{Mn}-\mathrm{Sb}$ phase diagram as a result of the data obtained by DTA, XRD, and SEM-EDX is shown in Fig. 2. The magnetic transition temperatures were taken from Massalski et al. ${ }^{[16]}$

\section{1 $\mathrm{Mn}_{2} \mathrm{Sb}$ Phase}

The homogeneity range and the congruent melting point of the phase $\mathrm{Mn}_{2} \mathrm{Sb}$ that were obtained here are not fully consistent with the values reported by Massalski et al. ${ }^{[18]}$ EDX results of samples in the adjacent two-phase fields, annealed at $600{ }^{\circ} \mathrm{C}, 725^{\circ} \mathrm{C}$, and $800{ }^{\circ} \mathrm{C}$, indicate a stability range for $\mathrm{Mn}_{2} \mathrm{Sb}$ between $33.7 \pm 0.7$ and $34.5 \pm 0.6$ at. $\%$ $\mathrm{Sb}$, more or less independent of temperature. Above $800{ }^{\circ} \mathrm{C}$, the homogeneity range of $\mathrm{Mn}_{2} \mathrm{Sb}$ becomes narrower, approaching the congruent melting point. The extrapolated onsets of the melting peaks of samples inside the $\mathrm{Mn}_{2} \mathrm{Sb}$ stability phase field were between $901{ }^{\circ} \mathrm{C}$ and $902{ }^{\circ} \mathrm{C}$, indicating a congruent melting point at $901 \pm 1{ }^{\circ} \mathrm{C}$.

These results are in contrast to the values reported in the literature. The homogeneity range is narrower than shown by Massalski et al., ${ }^{[18]}$ and it is also slightly different from the results by Askheim and Grønvold ${ }^{[9]}$ who described the composition of $\mathrm{Mn}_{2} \mathrm{Sb}$ as 33.3 at. $\% \mathrm{Sb}$ at 600 to $700{ }^{\circ} \mathrm{C}$ and 


\begin{tabular}{|c|c|c|c|c|c|}
\hline \multirow[b]{3}{*}{ Sample comp./at\% } & \multirow[b]{3}{*}{ Annealing duration $/$ temp. $\mathbf{h} /{ }^{\circ} \mathrm{C}$} & \multicolumn{4}{|c|}{ Thermal analysis } \\
\hline & & \multicolumn{3}{|l|}{ Heating $/{ }^{\circ} \mathrm{C}$} & \multirow{2}{*}{$\begin{array}{c}\text { Cooling } /{ }^{\circ} \mathrm{C} \\
\text { Liquidus }\end{array}$} \\
\hline & & Invariant effects & Other effects & Liquidus & \\
\hline $\mathrm{Mn}_{15} \mathrm{Sb}_{85}$ & $340 / 600$ & 566 & $\ldots$ & 593 & 576 \\
\hline $\mathrm{Mn}_{21} \mathrm{Sb}_{79}$ & $340 / 600$ & 566 & $\ldots$ & 602 & 599 \\
\hline $\mathrm{Mn}_{25.6} \mathrm{Sb}_{74.4}$ & $340 / 600$ & 565 & $\ldots$ & 628 & 633 \\
\hline $\mathrm{Mn}_{31.8} \mathrm{Sb}_{68.2}$ & $384 / 725$ & 566 & $\ldots$ & 654 & 654 \\
\hline $\mathrm{Mn}_{39.3} \mathrm{Sb}_{60.7}$ & $340 / 750$ & 566 & $\ldots$ & 728 & 733 \\
\hline $\mathrm{Mn}_{49.4} \mathrm{Sb}_{50.6}$ & $384 / 725$ & 568 & $\ldots$ & 807 & 771 \\
\hline $\mathrm{Mn}_{51.5} \mathrm{Sb}_{48.5}$ & $340 / 725$ & $\ldots$ & 760 & 822 & 819 \\
\hline $\mathrm{Mn}_{52.7} \mathrm{Sb}_{47.3}$ & $340 / 725$ & $\ldots$ & 789 & 828 & 820 \\
\hline $\mathrm{Mn}_{54.5} \mathrm{Sb}_{45.5}$ & $\underline{384 / 725}$ & $\ldots$ & $\underline{814}$ & 830 & $\underline{819}$ \\
\hline$\overline{\mathrm{Mn}_{55} \mathrm{Sb}_{45}}$ & 4 & $\underline{829}$ & $\overline{821}$ & $\overline{834}$ & $\overline{825}$ \\
\hline$\overline{\mathrm{Mn}_{56} \mathrm{Sb}_{44}}$ & $\overline{480 / 800}$ & $\overline{829}$ & $\ldots$ & 837 & $\overline{834}$ \\
\hline$\overline{\mathrm{Mn}}_{57.1} \mathrm{Sb}_{42.9}$ & $\underline{480 / 800}$ & $\underline{828}$ & $\ldots$ & $\overline{840}$ & $\overline{835}$ \\
\hline$\overline{\mathrm{Mn}_{59.8} \mathrm{Sb}_{40.2}}$ & $\ldots$ & $\overline{830}$ & $\ldots$ & $\overline{856}$ & $\overline{846}$ \\
\hline $\mathrm{Mn}_{62} \mathrm{Sb}_{38}$ & $480 / 600$ & 829 & $\ldots$ & 882 & 866 \\
\hline $\mathrm{Mn}_{66} \mathrm{Sb}_{34}$ & $480 / 725$ & $\ldots$ & $\ldots$ & 902 & 900 \\
\hline $\mathrm{Mn}_{66.1} \mathrm{Sb}_{33.9}$ & $480 / 725$ & $\ldots$ & $\ldots$ & 901 & 903 \\
\hline $\mathrm{Mn}_{67.5} \mathrm{Sb}_{32.5}$ & $480 / 600$ & 888 & $\ldots$ & 900 & 894 \\
\hline $\mathrm{Mn}_{72.9} \mathrm{Sb}_{27.1}$ & $480 / 725$ & 884 & $\ldots$ & 923 & 896 \\
\hline $\mathrm{Mn}_{76.7} \mathrm{Sb}_{23.3}$ & $480 / 600$ & $882 ; 902$ & $\ldots$ & 953 & 890 \\
\hline $\mathrm{Mn}_{83.7} S b_{16.3}$ & $480 / 250$ & $717 ; 894$ & $\ldots$ & 1073 & 1076 \\
\hline $\mathrm{Mn}_{92.7} \mathrm{Sb}_{7.3}$ & $480 / 600$ & $717 ; 894$ & 1009 & 1133 & 1122 \\
\hline $\mathrm{Mn}_{94.05} \mathrm{Sb}_{5.95}$ & $480 / 600$ & $719 ; 894$ & 1115 & 1181 & 1145 \\
\hline $\mathrm{Mn}_{94.6} S b_{5.4}$ & $480 / 725$ & 892 & $652 ; 1151$ & 1187 & 1182 \\
\hline $\mathrm{Mn}_{96} \mathrm{Sb}_{4}$ & $480 / 725$ & 720 v.w. & $976 ; 1154$ & 1193 & 1136 \\
\hline
\end{tabular}

32.4 at. $\% \mathrm{Sb}$ at $250{ }^{\circ} \mathrm{C}$. A strong evidence for a narrower $\mathrm{Mn}_{2} \mathrm{Sb}$ phase field is the occurrence of an invariant effect at $888{ }^{\circ} \mathrm{C}$ and a liquidus at $900{ }^{\circ} \mathrm{C}$ in a sample $\mathrm{Mn}_{67.5} \mathrm{Sb}_{32.5}$ for which the presence of $\alpha$-Mn was also clearly observed in the XRD pattern at $600{ }^{\circ} \mathrm{C}$. In fact, there were only two samples, $\mathrm{Mn}_{66.1} \mathrm{Sb}_{33.9}$, and $\mathrm{Mn}_{66} \mathrm{Sb}_{34}$ in which $\mathrm{Mn}_{2} \mathrm{Sb}$ was observed as single phase. The lattice parameters of $\mathrm{Mn}_{2} \mathrm{Sb}$, listed in Table 1, do not change significantly with composition; they agree very well with the values listed in Askheim and Grønvold ${ }^{[9]}$ and, more recently, reported by Ryzhkovskii et al. ${ }^{[14]}$

\subsection{MnSb Phase}

The shape of the MnSb phase field as it is shown in the literature ${ }^{[12,18,26]}$ is rather peculiar: a marked retrograde solubility on the Mn-rich side and a phase boundary on the $\mathrm{Sb}$-rich side that shifts distinctly to higher $\mathrm{Sb}$ contents with decreasing temperature. In addition, the peritectic composition of $\mathrm{MnSb}$ is very close to the composition of the liquid at the peritectic reaction.

Thus, it was considered possible that $\mathrm{MnSb}$ has actually a congruent melting point slightly higher than a eutectic reaction between $\mathrm{Mn}_{2} \mathrm{Sb}$ and $\mathrm{MnSb}$. This suspicion was nurtured by micrographs of samples in the composition range between $\mathrm{Mn}_{2} \mathrm{Sb}$ and $\mathrm{MnSb}$, both in the literature (see e.g. Yuan et al. ${ }^{[23]}$ ) as well as in present samples (Fig. 3a).

Therefore, a large number of samples was placed in the composition range between about 35 and 50 at.\% $\mathrm{Sb}$, and very careful DTA measurements were performed (Table 2). Four samples between 42.9 and 45.5 at.\% $\mathrm{Sb}$ (underlined in Table 2) were measured with a heating/cooling rate of $0.5 \mathrm{~K} / \mathrm{min}$ in order to be able to distinguish possibly overlapping thermal effects. In addition, two DTA-measurements were made where one sample was measured versus another one as reference $\left(\mathrm{Mn}_{56} \mathrm{Sb}_{44}\right.$ vs. $\mathrm{Mn}_{54.5} \mathrm{Sb}_{45.5}$ and $\mathrm{Mn}_{62} \mathrm{Sb}_{38}$ vs. $\mathrm{Mn}_{54.5} \mathrm{Sb}_{45.5}$ ) in order to clearly distinguish which one shows the lower liquidus temperature (see Fig. 4). As can be seen in Fig. 4, the heating curve shows an apparently exothermic effect at $815^{\circ} \mathrm{C}$ (onset) which is actually the solidus effect in the reference sample, i.e. in the one with the higher $\mathrm{Sb}$ content. This is followed by an endothermal effect with the onset at $829^{\circ} \mathrm{C}$ and the maximum at $837^{\circ} \mathrm{C}$, obviously corresponding to the peritectic reaction and the liquidus effect in the sample (with the lower $\mathrm{Sb}$ content).

The combined results indicate that $\mathrm{MnSb}$ does actually decompose in a peritectic reaction, as shown in the literature 


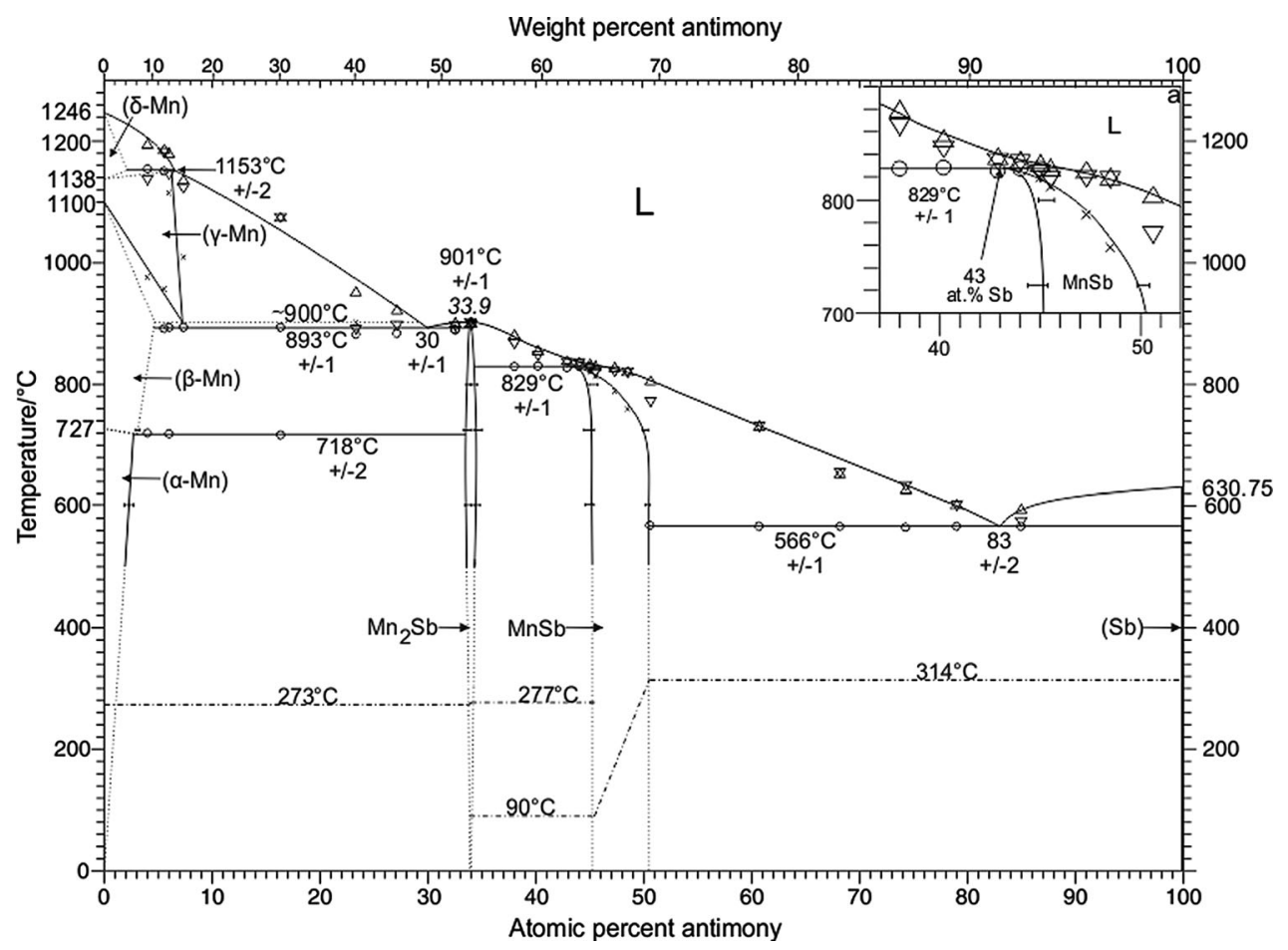

Fig. $2 \mathrm{Mn}$-Sb phase diagram according to present results. The insert shows a detail section in the composition range of the MnSb phase. The magnetic transitions (dashed dotted lines) were taken from Massalski et al. ${ }^{[16]}$ Circles: invariant thermal effects; triangles up: liquidus on heating; triangles down: liquidus on cooling; crosses: thermal effects related to phase boundaries; horizontal bars: error margin of phase boundaries according to SEM results

$\left(L+M n_{2} S b \rightarrow M n S b\right)$, at $829 \pm 1{ }^{\circ} \mathrm{C}$ and about 43 at.\% $\mathrm{Sb}$. This temperature is more than $10{ }^{\circ} \mathrm{C}$ lower than reported previously ${ }^{[12,18,24,26]}$ whereas the peritectic composition of $\mathrm{MnSb}$ is at a somewhat higher Sb content. Interpretation of DTA data (Table 2) and phase composition measurements of samples containing 38.0 to 81.6 at.\% $\mathrm{Sb}$ result in a phase field for $\mathrm{MnSb}$ as shown in Fig. 2.

These results seem to contradict the appearance of micrographs of various samples. For example, the micrograph of a sample $\mathrm{Mn}_{59.8} \mathrm{Sb}_{40.2}$ that had been quenched from the melt shows a structure similar to a laminar eutectic texture with an average composition of approximately $\mathrm{Mn}_{58.2} \mathrm{Sb}_{42.8}$ (Fig. 3a). A similar micrograph had also been observed by Yuan et al. ${ }^{[23]}$ It must be concluded that the fine lamellae of $\mathrm{Mn}_{2} \mathrm{Sb}$ precipitate out of the $\mathrm{MnSb}$ crystals on cooling due to the marked retrograde solubility. This is in line with the observations by Chen et al. ${ }^{[26]}$ who observed similar precipitations of $\mathrm{Mn}_{2} \mathrm{Sb}$ in their $\mathrm{MnSb}$ single crystals. Due to the small difference in composition between the liquid phase and $\mathrm{Mn}_{2} \mathrm{Sb}$ in the peritectic reaction the typical peritectic microstructure cannot develop.

It is interesting that Teramoto and van Run ${ }^{[24]}$ observed between 820 and $500{ }^{\circ} \mathrm{C}$ an almost temperature independent Mn-rich phase boundary of $\mathrm{MnSb}$ ( $\sim 45.5$ at.\% Sb) from Curie temperature measurements on quenched samples which was in clear contrast to the DTA results. They concluded that the equilibrium was frozen in at a temperature of about $550{ }^{\circ} \mathrm{C}$ whereas at higher temperatures quenching was not able to preserve the correct phase equilibrium.

\subsection{Mn-Rich Part of the System $\left(x_{S b}<0.33\right)$}

The results obtained in this part of the system differ somewhat from data reported in literature. ${ }^{[18]}$ In particular, DTA results of samples at 4.0 and 5.4 at.\% $\mathrm{Sb}$ show an invariant reaction at $1153 \pm 2{ }^{\circ} \mathrm{C}$ which is interpreted as the peritectic formation of $\gamma-\mathrm{Mn}, L+\delta-M n \rightarrow \gamma-M n$, which is approximately $50{ }^{\circ} \mathrm{C}$ lower than shown in Massalski et al. ${ }^{[18]}$ The homogeneity range of $\gamma-\mathrm{Mn}$ was derived from the DTA results of four samples between 4.0 and 7.3 at.\% $\mathrm{Sb}$ (see Fig. 2 and 5). The metatectic reaction $\gamma-\mathrm{Mn} \rightarrow \beta$ $\mathrm{Mn}+\mathrm{L}$ is estimated at about $900{ }^{\circ} \mathrm{C}$ from the DTA results of only one sample $\left(\mathrm{Mn}_{76.7} \mathrm{Sb}_{23.3}\right)$ measured in a silica glass crucible where an effect was observed at $902{ }^{\circ} \mathrm{C}$. Not finding this effect at about $900{ }^{\circ} \mathrm{C}$ in other samples with compositions nearby is related to measuring these in Tacrucibles where the resolution is not sensitive enough to detect this rather small effect.

The investigation of the eutectic reaction $L \rightarrow \beta$ $\mathrm{Mn}+\mathrm{Mn}_{2} \mathrm{Sb}$ showed some differences depending on the crucible material used for the DTA measurements. Significant deviations were observed in the samples ranging from 5.4 to 32.5 at.\% $\mathrm{Sb}$ with average temperatures of $888^{\circ} \mathrm{C}$ when measured in silica glass crucibles and $893{ }^{\circ} \mathrm{C}$ in Tacrucibles. Due to the observed reactions between $\mathrm{Mn}$ and the carbonized silica glass tubes which will certainly influence the measurements, the values obtained with the Ta crucibles are preferred, and the eutectic temperature is shown at $893 \pm 1{ }^{\circ} \mathrm{C}$. Again, this temperature is considerably lower than the value of $922{ }^{\circ} \mathrm{C}$ in Massalski et al. ${ }^{[18]}$ 
(a)
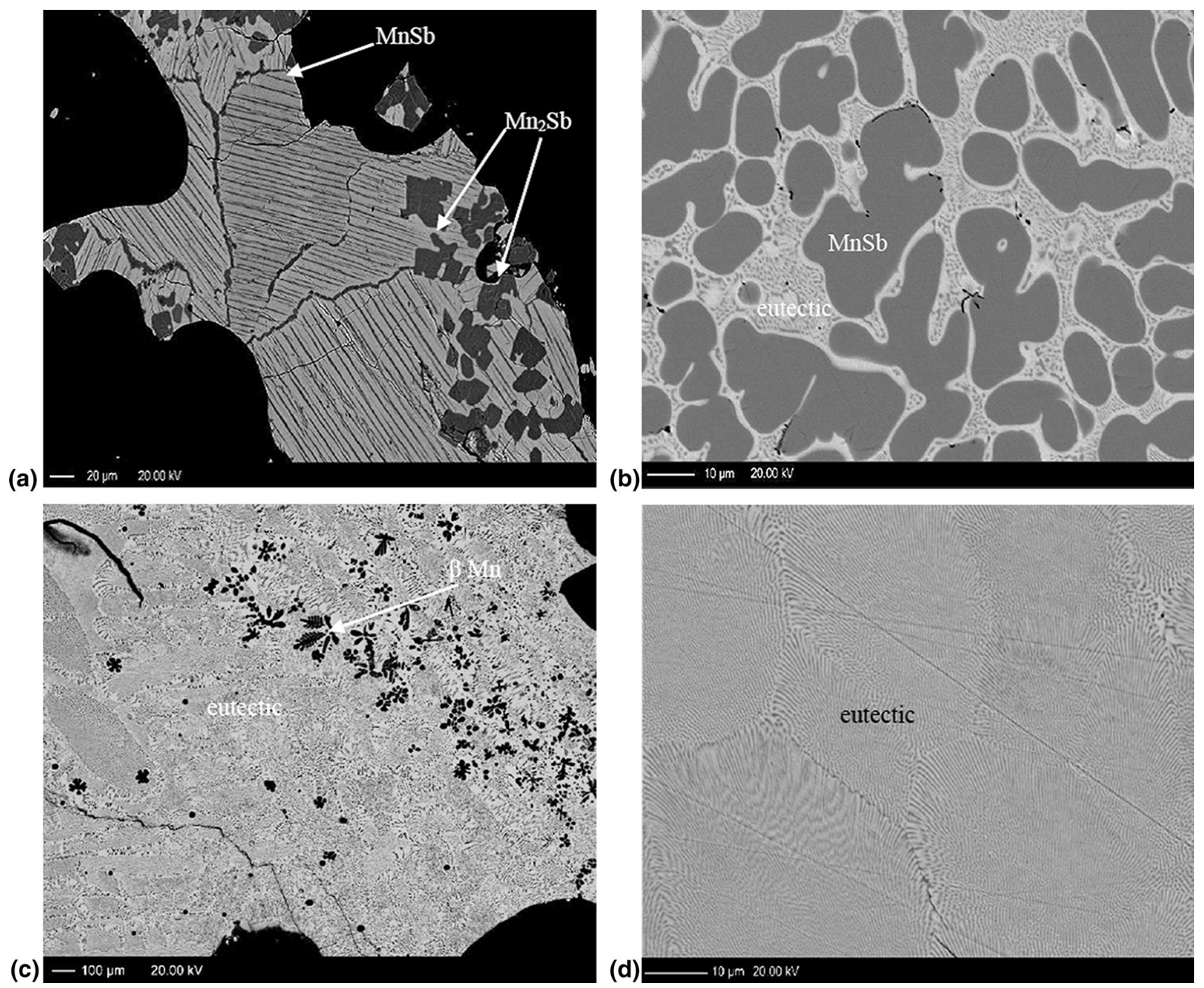

Fig. 3 SEM backscattered electron images of selected samples (black structures are either holes or cracks caused by sample preparation). (a) $\mathrm{Mn}_{59.8} \mathrm{Sb}_{40.2}$, quenched from the melt, shows $\mathrm{Mn}_{2} \mathrm{Sb}$ primary crystals (dark) and bright MnSb with fine needles of precipitated $\mathrm{Mn}_{2} \mathrm{Sb}$. (b) $\mathrm{Mn}_{39.3} \mathrm{Sb}_{60.7}$, annealed at $750{ }^{\circ} \mathrm{C}$, shows $\mathrm{MnSb}$ (dark gray) surrounded by eutectic matrix. (c) $\mathrm{Mn}_{72.9} \mathrm{Sb}_{27.1}$, annealed at $725{ }^{\circ} \mathrm{C}$, shows a eutectic structure close to the eutectic point of $30 \pm 1$ at.\% Sb together with $\beta$-Mn (dark). (d) $\mathrm{Mn}_{18.4} \mathrm{Sb}_{81.6}$, annealed at ${ }^{\circ} \mathrm{C}$, shows a eutectic structure close to the eutectic point of $83 \pm 1$ at. $\% \mathrm{Sb}$

The eutectic point itself was determined at $30 \pm 1$ at.\% $\mathrm{Sb}$ from the SEM-EDX results of a number of samples and from the extrapolation of the liquidus lines; it is in reasonable agreement with the reported value of 27 at.\% Sb by Massalski et al. ${ }^{[18]}$

The invariant reaction temperature of $718 \pm 2{ }^{\circ} \mathrm{C}$ for the eutectoid reaction $\beta-M n \rightarrow \alpha-M n+M n_{2} S b$ was measured in Ta crucibles and is higher than the reported value of $677^{\circ} \mathrm{C}^{[18]}$. It only appeared in the first heating run and could not be detected on cooling nor on second heating. It was not found in samples with more less than 20 at.\% Sb, obviously because the heat effect involved in this solid state transformation is rather small. EDX investigations of the solubility range of $\mathrm{Sb}$ in $\alpha-\mathrm{Mn}$ in several samples indicated a solubility of $2.3 \pm 0.9$ at. $\% \mathrm{Sb}$ at $600{ }^{\circ} \mathrm{C}$ and in $\beta-\mathrm{Mn}$ $3.1 \pm 0.2$ at. $\% \mathrm{Sb}$ at $725^{\circ} \mathrm{C}$.

\subsection{Sb-Rich Part of the System $\left(x_{S b}>0.5\right)$}

DTA investigations (Table 2) of the samples containing between 50.6 and 85 at.\% $\mathrm{Sb}$ revealed a eutectic reaction $L \rightarrow M n S b+S b$ at a temperature of $566 \pm 1^{\circ} \mathrm{C}$, and the eutectic point was determined at $83 \pm 2$ at.\% Sb from EDX results of various samples and an extrapolation of the liquidus line. This is in good agreement with the values reported by Massalski et al., Liu et al. ${ }^{[18,27]}$ i.e. $570{ }^{\circ} \mathrm{C}$ and 81 at. $\% \mathrm{Sb}$.

\subsection{Lattice Parameters of the MnSb Phase}

The unit cell parameters $a, c$, the ratio $c / a$ and the cell volume $V$ of the $\mathrm{MnSb}$ phase, measured powders quenched from 725 or $800{ }^{\circ} \mathrm{C}$, respectively, are shown in Fig. 6(a)-(d) together with the values of Teramoto and van $\operatorname{Run}^{[24]}$ as 


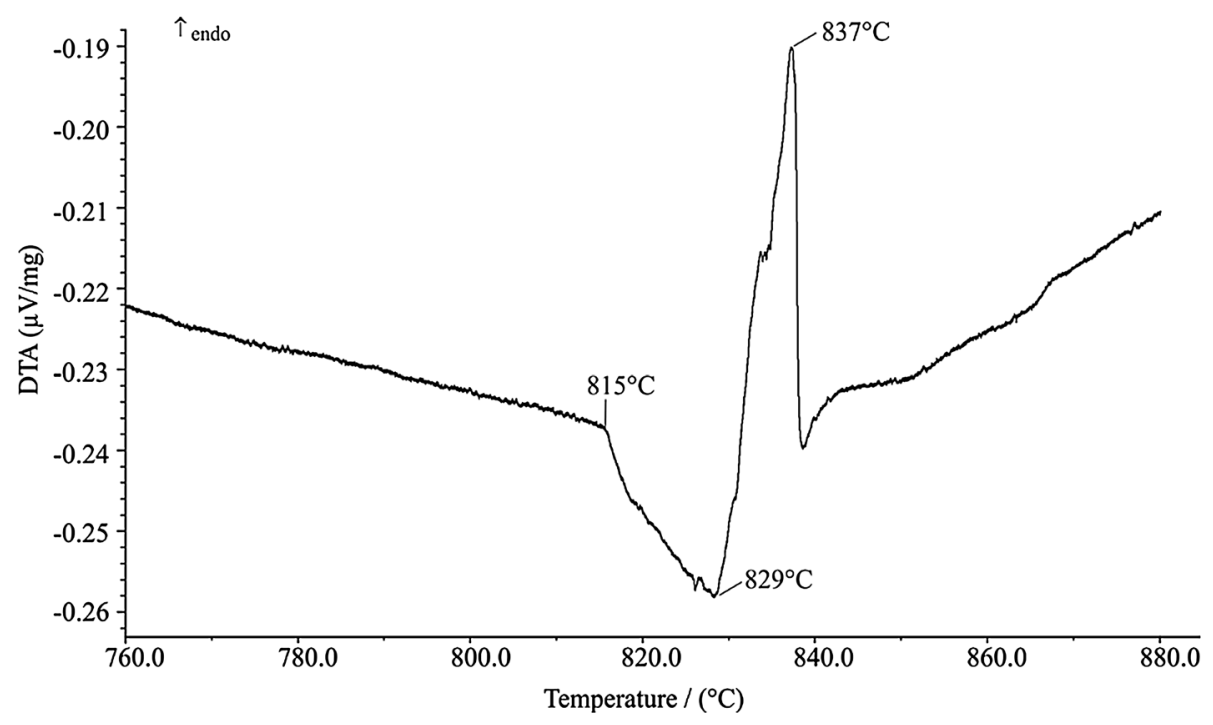

Fig. 4 DTA heating curve of $\mathrm{Mn}_{56} \mathrm{Sb}_{44}$ measured vs. $\mathrm{Mn}_{54.5} \mathrm{Sb}_{45.5}$ as reference

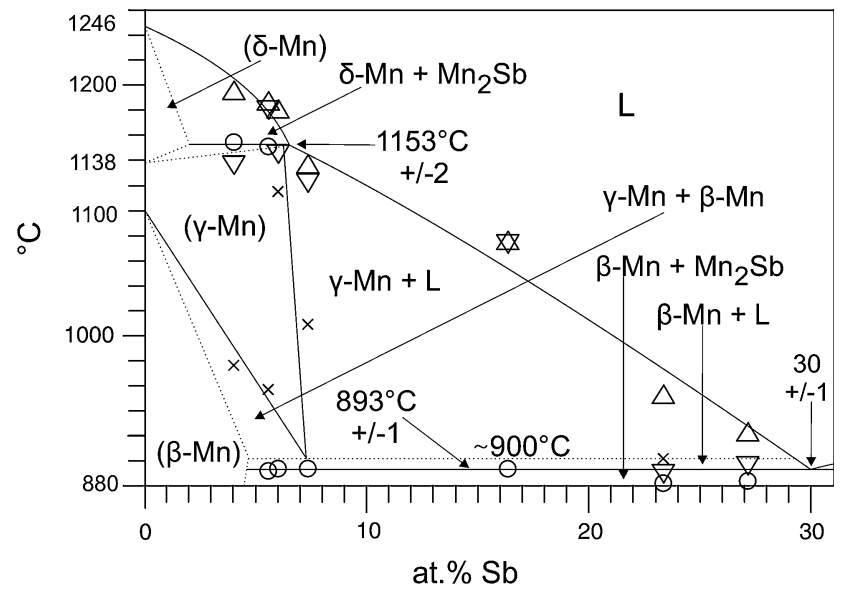

Fig. 5 Detail of the $\mathrm{Mn}$ rich part of the Mn-Sb phase diagram. Circles: invariant thermal effects; triangles up: liquidus on heating; triangles down: liquidus on cooling; crosses: thermal effects related to phase boundaries

well as Chen et al. ${ }^{[26]}$ For the sample with 50.6 at.\% Sb, a small amount of $\mathrm{Sb}$ was detected by XRD which is in good agreement with the phase boundary shown in Fig. 2 . Comparison of the obtained results with those of Teramoto and van Run $^{[24]}$ and Chen et al. ${ }^{[26]}$ shows reasonable agreement whereas the values of Romaka et al. ${ }^{[25]}$ deviate considerably. In fact, these latter authors describe an increase in lattice parameters $a$ (from 4.144(3) to 4.151(4)
$\AA$ ) and $c$ (from 5.773(2) to 5.785(3) $\AA$ ) with increasing $\mathrm{Sb}$ content from 46 to 53 at.\%. This elongation in both parameter leads to a volume increase from 85.856(13) to $86.325(17) \AA^{3}$, which is in clear contradiction to the general behavior of NiAs-type phases, i.e. decreasing volume with decreasing content of the transition metal in the unit cell.

As can be seen in Fig. 6(a)-(d), the lattice parameter $a$ decreases whereas the lattice parameter $c$ increases with increasing Sb content; the $c / a$ ratio increases in the same direction and lies between about 1.35(1) and 1.39(2), which is in the typical range of the NiAs structure as pointed out by Brand et al. ${ }^{[29]}$ but far away from the ratio $c / a=1.633$, which represents the ideal value for hexagonally closed packing. The cell volume versus $\mathrm{Sb}$ content decreases from about 88.52(1) to 86.05(5) $\AA^{3}$ with increasing Sb content. This trend in the cell volume and the cla ratio indicates that the structure undergoes a continuous change from the NiAs to the disordered $\mathrm{Ni}_{2} \mathrm{In}$ structure type with increasing $\mathrm{Mn}$ content.

\section{Summary}

The complete $\mathrm{Mn}-\mathrm{Sb}$ phase diagram above about $500{ }^{\circ} \mathrm{C}$ was investigated by standard experimental methods and is presented in Fig. 2. Based on the present results, the homogeneity ranges of the intermetallic compounds $\mathrm{Mn}_{2} \mathrm{Sb}$ and $\mathrm{MnSb}$ were reassessed. All invariant reactions were determined by DTA measurements and are listed in Table 3. The peritectic formation of $\mathrm{MnSb}$, as reported by Massalski 

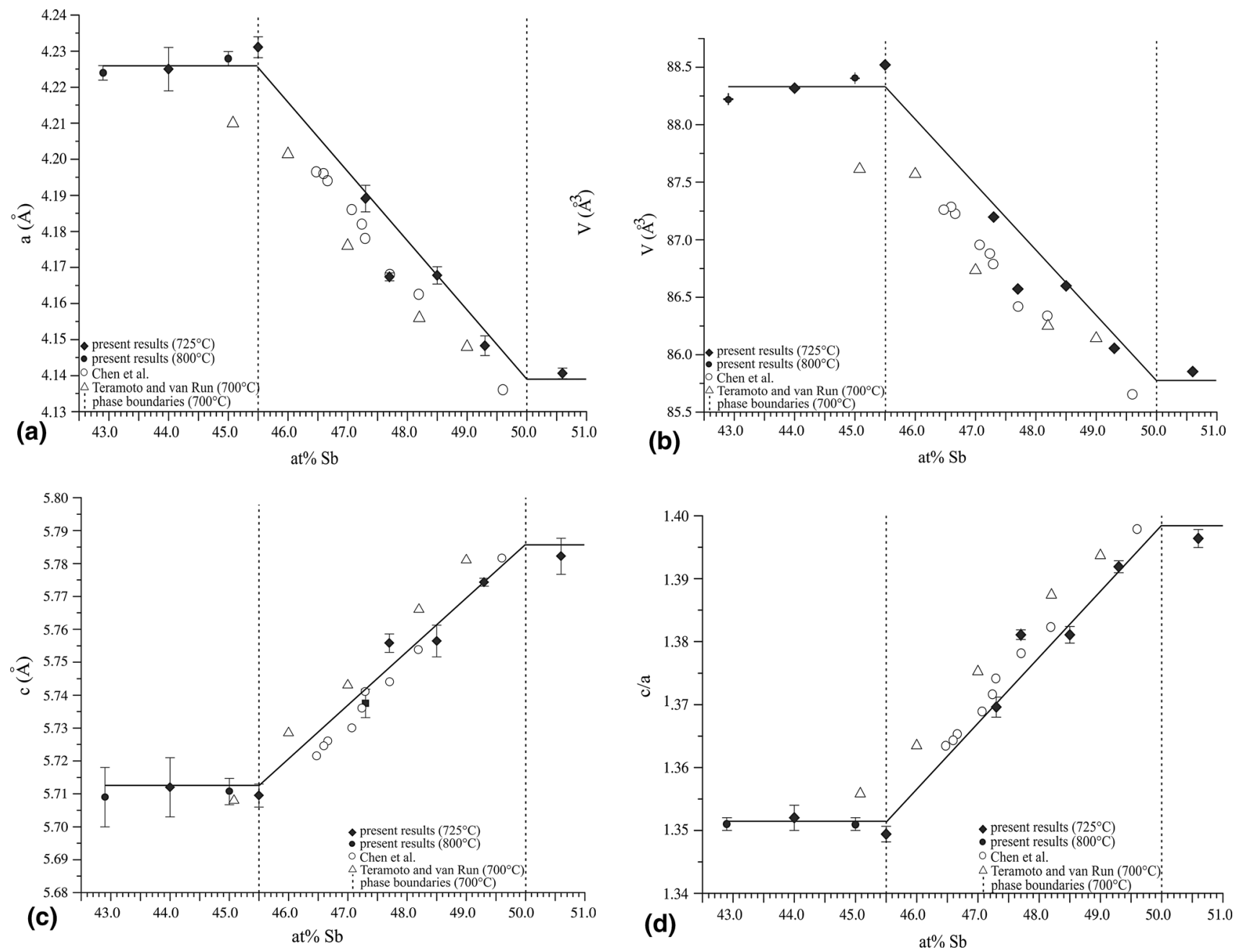

Fig. 6 Lattice parameters $a, c, c / a, V$ of $\mathrm{MnSb}$ as a function of $\mathrm{Sb}$ concentration

Table 3 Invariant reactions in the Mn-Sb system

\begin{tabular}{|c|c|c|c|c|c|}
\hline Reaction & \multicolumn{3}{|c|}{ Composition/at.\% Sb } & Temp. $/{ }^{\circ} \mathrm{C}$ & Reaction type \\
\hline $\mathrm{L}+\delta-\mathrm{Mn} \rightarrow \gamma-\mathrm{Mn}$ & 2 & 6.1 & 6.5 & $1153 \pm 2$ & peritectic \\
\hline $\mathrm{L} \rightarrow \mathrm{Mn}_{2} \mathrm{Sb}$ & $\ldots$ & 33.9 & $\ldots$ & $901 \pm 1$ & congruent \\
\hline$\gamma-\mathrm{Mn} \rightarrow \beta-\mathrm{Mn}+\mathrm{L}$ & 4.7 & 8.0 & 29.2 & $\sim 900$ & metatectic \\
\hline $\mathrm{L} \rightarrow \beta-\mathrm{Mn}+\mathrm{Mn}_{2} \mathrm{Sb}$ & 4.5 & $30 \pm 1$ & 33.8 & $893 \pm 1$ & eutectic \\
\hline $\mathrm{L}+\mathrm{Mn}_{2} \mathrm{Sb} \rightarrow \mathrm{MnSb}$ & 34.2 & 43 & 46.2 & $829 \pm 1$ & peritectic \\
\hline$\beta-\mathrm{Mn} \rightarrow \alpha-\mathrm{Mn}+\mathrm{Mn}_{2} \mathrm{Sb}$ & 3.1 & 4.3 & 33.6 & $718 \pm 2$ & eudectoid \\
\hline $\mathrm{L} \rightarrow \mathrm{MnSb}+\mathrm{Sb}$ & 50.5 & $83 \pm 2$ & 99.9 & $566 \pm 1$ & eutectic \\
\hline
\end{tabular}

Italics: estimated concentration values

et al., ${ }^{[18]}$ could be confirmed although the peritectic composition (44.6 at.\% Sb) had to be shifted to the Sbrich side by about 4 at.\% and the reaction temperature $\left(829 \pm 1{ }^{\circ} \mathrm{C}\right)$ is about $10{ }^{\circ} \mathrm{C}$ lower. The homogeneity range of $\mathrm{Mn}_{2} \mathrm{Sb}$ is narrower than reported previously.

\section{Acknowledgments}

We wish to thank the FWF (Austria Science Fund) financial support of this work through project No. P 26023N19. Many thanks also to Dr. Stephan Puchegger from the 
Center for Nano Structure Research, University of Vienna, for supporting our SEM/EDX measurements.

\section{Open Access}

This article is distributed under the terms of the Creative Commons Attribution 4.0 International License (http:// creativecommons.org/licenses/by/4.0/), which permits unrestricted use, distribution, and reproduction in any medium, provided you give appropriate credit to the original author(s) and the source, provide a link to the Creative Commons license, and indicate if changes were made.

\section{References}

1. F. Heusler, Über magnetische Manganlegierungen (On Magnetic Manganese Alloys), Ber. Deut. Phys. Ges., 1903, 12, p 219-228 (in German)

2. F. Heusler, Über die ferromagnetischen Eigenschaften von Legierungen unmagnetischer Metalle (On the Ferromagnetic Properties of Alloys of Nonmagnetic Metals), Z. Anorg. Chem., 1904, 17, p 260-280, (in German)

3. E. Wedekind, Die Magnetisierbarkeit magnetischer Verbindungen aus unmagnetischen Elementen (The Magnetic Properties of Compounds of Non-magnetic Elements), Z. Physik. Chem., 1910, 66, p 614-632, (in German)

4. C. Guillaud, "Ferromagnetisme des alliages binaires de manganese," Ph.D. Thesis, Strassburg, 1943

5. M.K. Wilkinson, N.S. Gingrich, and C.G. Shull, The Magnetic Structure of $\mathrm{Mn}_{2} \mathrm{Sb}$, J. Phys. Chem. Solids, 1957, 2, p 289-300

6. H.A. Alperin, P.J. Brown, and R. Nathans, Aspherical Spin Density in the Ferrimagnetic Compound $\mathrm{Mn}_{2} \mathrm{Sb}, J$. Appl. Phys., 1963, 34, p 1201-1202

7. I. Moritani, N. Nakayama, and T. Shinjo, Magnetic Properties of $\mathrm{MnSb} / \mathrm{Sb}$ Superlattices, J. Mag. Mag. Mater., 1990, 90, p 307-308

8. F.J. Darnell, W.H. Cloud, and H.S. Jarvett, X-Ray and Magnetization Studies of Cr-Modified $\mathrm{Mn}_{2} \mathrm{Sb}$, Phys. Rev. E, 1963, 130, p 647-655

9. N.E. Askheim and F. Grønvold, The $\mathrm{Mn}_{2} \mathrm{Sb}$ Phase-Composition and Thermodynamic Properties in the Range 298 to 1000 K, J. Chem. Thermodyn., 1969, 1, p 153-167

10. R.S. Williams, Über die Legierungen des Antimons mit Mangan, Chrom, Silicium und Zinn; des Wismuts mit Chrom und Silicium und des Mangans mit Zinn und Blei (On the Alloys of Antimony with Manganese, Chromium, Silicon and Tin; of Bismuth with Chromium and Silicon and of Manganese with Tin and Lead), Z. Anorg. Chem., 1907, 55, p 1-33, (in German)

11. H. Halla and H. Nowotny, X-ray Investigation in the System Manganese-Antimony, Z. Physik. Chem. B, 1936, 34, p 141-144

12. V.G. Vanyarkho, N.A. Moshchalkova, V.M. Gunchenko, and N.V. Fadeeva, On the Existence of the Compound MnSb, Izv. Akad. Nauk SSSR, Neorg. Mater., 1988, 24(6), p 900-903,(in Russian)
13. Y. Pan and G.X. Sun, Directional Solidification and Magnetic Properties of MnSb-Sb Eutectic Composite, J. Mater. Sci., 1998, 33, p 763-768

14. V.M. Ryzhkovskii, V.P. Glazkov, V.S. Goncharov, D.P. Kozlenko, and B.N. Savenko, Neutron Diffraction Investigation of the Magnetic Structure of the $\mathrm{Mn}_{2} \mathrm{Sb}$ Pnictide at High Pressures, Phys. Solid State, 2002, 44, p 2281-2286

15. V.S. Goncharov and V.M. Ryzhkovskii, Phase Separation of $\mathrm{Mn}_{2} \mathrm{Sb}$ at High Pressures and Temperatures, Inorg. Mater. 2011, 47(12), p 1298-1301

16. T. Yamashita, H. Takizawa, T. Sasaki, K. Uheda, and T. Endo, $\mathrm{Mn}_{3} \mathrm{Sb} \mathrm{A}$ New L1 $1_{2}$-Type Intermetallic Compound Synthesized Under High-Pressure, J. Alloys Compd., 2003, 348, p 220-223

17. V.M. Ryzhkovskii and V.S. Goncharov, Effect of HighPressure High-Temperature Processing on the Phase Composition and Magnetic State of $\mathrm{Mn}_{1}+\mathrm{xSb}(0 \leq \mathrm{x} \leq 1.0)$ Alloys, Inorg. Mater., 2010, 46(3), p 226-231

18. T.B. Massalski, H. Okamoto, P.R. Subramanian, and L. Kacprzak, Eds., Binary Alloy Phase Diagrams, 2nd ed., ASM International, Materials Park, OH, 1992, p 2598

19. P.B. Landolt-Börnstein, Group IV: Physical Chemistry, Vol. 5: Phase Equilibria, Crystallographic and Thermodynamic Data of Binary Alloys, Subvol. H, Springer, Heidelberg, 1998, p 143-144

20. I. Oftedal, Über einige Kristallstrukturen vom Typus NiAs (Some Crystal Structures of the Type NiAs), Z. Physik. Chem., 1927, 28, p 135-153, (in German)

21. T. Murakami and A. Hatta, Equilibrium Diagram of the Antimony-Manganese System, Sci. Rep. Tohoku Univ., 1933, 22, p 88-100

22. A. Kjekshus and W.B. Pearson, Phases with the Nickel Arsenide and Closely Related Structures, Prog. Solid State Chem., 1964, 1, p 83-174

23. Y. Yuan, Y.-L. Li, Q. Wang, T. Liu, G. Tie, P.-F. Gao, and J.-Ch. He, Influence of High Magnetic Fields on Phase Transition and Solidification Microstructure in Mn-Sb Peritectic Alloy, Acta Phys. Sin. 2013, 62(20), p. 208106-1-208106-7

24. I. Teramoto and A.M.J.G. van Run, Existence Region and the Magnetic and Electrical Properties of MnSb, J. Phys. Chem. Solids, 1968, 29, p 347-355

25. L. Romaka, A. Tkachuk, Yu Stadnyk, V.V. Romaka, A. Horyn, and R. Korzh, Peculiarity of Component Interaction in Zr-Mn-Sn, Sb) Ternary Systems, J. Alloys Compd., 2014, 611, p 401-409

26. Tu Chen, G.B. Charlan, and R.C. Keezer, Growth of MnSb Single Crystals by Pulling with a Seed from Nonstoichiometric Molten Solution, J. Cryst. Growth, 1977, 37, p 29-36

27. T. Liu, Q. Wang, A. Gao, H. Zhang, and J. He, Effects of a High Magnetic Field on the Phase Equilibria of Mn-Sb System During Solidification Process, J. Alloys Compd., 2011, 509, p 5822-5824

28. TOPAS 4.2, Bruker AXS Inc., Karlsruhe, Germany, 2011

29. P. Brand, Über Umwandlungen in Phasen vom aufgefüllten NiAs- (NiIn-) Strukturtyp (Phase Transitions in the NiAs( $\left.\mathrm{Ni}_{2} \mathrm{In}\right)$ Structure Type), Z. Anorg. Allg. Chem., 1967, 353, p 270-280

30. M. Uemitsu, M. Enoki, S. Iikubo, and H. Ohtani, Thermodynamic Analysis of Phase Equilibria in the Mn-Bi-Sb System, Trans. Jpn. Inst. Met. Mater., 2014, 78, p 327-336 (in Japanese) 